\title{
How individual cognitions overshadow regulations and group norms: a study of government venture capital decisions
}

\author{
Jeaneth Johansson • Malin Malmström • \\ Joakim Wincent • Vinit Parida
}

Accepted: 18 June 2019 / Published online: 26 October 2019

(C) The Author(s) 2019

\begin{abstract}
This paper explores how government venture capitalists approve or reject financing applications. Based on longitudinal observations, complemented by interviews, documentation, and secondary data, the findings show the limited influence of the regulative and normative logics (e.g., formal guidelines and accepted behavior) on government venture capitalists' decisions. Instead, individual decisions are observed to be largely overshadowed by cognitions and heuristics, which dominate formal regulations and socially constructed group-level norms. Although official decision communications state that regulations have been followed, the evidence suggests that the cognitive logic dominates the funding decision-making process through a
\end{abstract}

J. Johansson · M. Malmström · V. Parida

Entrepreneurship \& Innovation, Luleå University of Technology, SE-971 87 Luleå, Sweden

\section{J. Johansson $(\bowtie)$}

Center for Innovation, Entrepreneurship and Learning, Halmstad University, SE-301 18 Halmstad, Sweden

e-mail: jeaneth.johansson@hh.se

J. Wincent

Entrepreneurship, Management and Organisation, Hanken School of Business, P.O.Box 479, 00101 Helsinki, Finland

J. Wincent

Entrepreneurship \& Innovation, St Gallen University, CH-9000,

St. Gallen, Switzerland

V. Parida

School of Management, University of Vaasa, PO Box 700,

FI-65101 Vaasa, Finland set of overshadowing forces that restrict the influence of the normative and regulative logics on funding decisions. This research has implications for venture financing and highlights the importance of cognitions in shaping venture capital decisions.

Keywords Government investment - Venture financing · Venture capital · Entrepreneurship . Institutional theory $\cdot$ Decision making

JEL D01 · D23 · D25 · D73 · D81 · D91 - G24 · G28 · $\mathrm{G} 41 \cdot \mathrm{L} 26$

\section{Introduction}

The entrepreneurial finance literature highlights the need to understand a variety of financial sources besides traditional venture capital to better understand the financing of high-growth-potential ventures and heterogeneity in venture capitalist decision making (Block et al. 2018; Drover et al. 2017). Traditional venture capital research dominates the entrepreneurial finance literature, even though only $1 \%$ of ventures secure such funding (Drover et al. 2017; Kaplan and Lerner 2016). This paper focuses on government venture capitalists (GVCs), a relatively neglected group of financiers in the entrepreneurial finance literature (Colombo et al. 2016). Government venture capital (GVC) has been a key feature in extending the supply of financing to new and innovative ventures, specifically in their early phases, to ensure financial support for diverse types of 
entrepreneurs, minorities, and sectors and to support growth opportunities where external financial support is crucial (Gorman et al. 2005; Bertoni and Tykvová 2015). For example, based on the decisions of GVCs, the European Union (EU) allocated $€ 3.621$ billion to finance competitiveness and innovation in European ventures between 2007 and 2013. Taxpayers' money is the single largest source of venture capital, making GVCs quite unique and differentiating them from traditional venture capitalists (EVCA 2014). However, the impact and contribution of GVCs should not be underestimated. In 2014, governments in Europe provided $35 \%$ of early-stage venture finance (Invest Europe 2015). The magnitude of these figures is likely to be representative for numerous countries outside the EU (Bertoni and Tykvová 2015). Difficulties for ventures in raising finance are increasingly pertinent for international, national, and local government institutions. The trend of such support is expected to become even more important in the future (Block et al. 2018).

The conditions under which government financiers operate suggests that understanding the decisions behind government financial support is problematic and challenging. Government financial support is highly controversial because it represents the distribution of funds from the tax system and the transfer of public money to specific individual ventures with commercial interests. When financial support succeeds by allowing the development of successful ventures, it is argued that society as a whole receives future benefits in the form of employment growth and the creation of new technologies and innovations (Croce et al. 2018; Luukkonen et al. 2013). Despite the proposed benefits associated with government financial support, government financiers face greater scrutiny in relation to their decisionmaking processes. These financiers must respond to and consider multiple interests, including those of the market (e.g., finance, product, market, and management potential) and politicians (e.g., social responsibility, environmental, rural survival). This balancing act creates complex situations for GVCs to deal with and general uncertainty in predicting future business potential (Gorman et al. 2005; Leleux and Surlemont 2003; Luukkonen et al. 2013; Colombo et al. 2016).

In addition, as external evaluators in charge of making balanced, responsible decisions to distribute public funds to the private sector, GVCs are also at a disadvantage with respect to venture management, which may possess inside information that is difficult for government financiers to access (Gabrielsson and Huse 2002). Accordingly, these financiers make investment decisions in an uncertain and complex environment where multiple interests must be considered (Gorman et al. 2005). The value provided by GVC investments is heavily discussed in the literature, but the evidence of GVCs' effectiveness is mixed (Lerner 2002; Cumming and Johan 2019). GVC has had debatable results in many countries (Lerner 2012; Lerner and Watson 2008; Bertoni and Tykvová 2015). GVCs are nevertheless considered catalysts of regional economic development (Zhang 2018), aiming to support regional ventures in markets where traditional venture capital is thin. They thus complement traditional venture capital by bridging the financial gap (Bertoni and Tykvová 2015) and providing a certification effect in front of private venture capital, this by decreasing information asymmetry (Martí and Quas 2018). GVCs are expected to provide social value, yet failing to provide financial value may raise reputational concerns and questions over the public program and the GVCs' efficacy. There is an ongoing debate on how much social returns and rural survival should be allowed to cost (Abrardi et al. 2019; Colombo et al. 2016).

Many previous studies have considered the macro perspective of country-specific policies or have examined GVC programs and their impact on performance (Block et al. 2018; Brander et al. 2014; Cumming and MacIntosh 2007; Cumming et al. 2017). However, there is a lack of studies exploring the demands placed on GVCs in their decision-making processes. This study aims to reduce this gap by contributing to the entrepreneurial finance literature, particularly the venture capital literature, by enriching our understanding of institutional mechanisms and organizational behavior in GVCs' decision-making processes (Block et al. 2018; Drover et al. 2017). By providing rich empirical insights coupled with an inductive, longitudinal, qualitative study of the decision meetings of GVCs, we answer numerous questions related to government financiers' decision-making processes: How do GVCs balance regulative procedures, group norms, and their own cognitions or judgments when making decisions? How do they achieve balanced and responsible decisions concerning the distribution of public funds to the private sector? Are they able to make objective decisions that follow the regulations, or do they ultimately follow some other decision-making process?

Although the study was inductive, we found that GVCs' decision making was influenced by cognitive, 
regulative, and normative issues, which led us to draw on institutional theory (Scott 2014) to understand how GVCs make decisions. The institutional perspective enabled us to thoroughly explore the GVC sector, specifically the institutional pressure and the endeavor to capture organizational legitimacy and providing of venture support (Campbell 2004; Ruef and Scott 1998). The inductive findings also led us to draw on the literature on organizational decision making to understand the multiple pressures placed on GVCs and the bounded rationality enacted by GVCs in their decision making (Guler 2007). The combination of institutional theory and organizational behavior enabled us to enhance our understanding and extend the applicability of institutional behavior in the entrepreneurial finance context (cf. Guler 2007).

We provide insights into the institutional behavior that guides decision making, where institutional regulations, norms, and cognitions are typically not aligned (Greenwood et al. 2011; Lawrence et al. 2011). Accordingly, this study makes a theoretical contribution to the institutional theory dialog by showing how dominant logics influence decision-making processes in the GVC context (Bertoni et al. 2015). A key finding is that cognitive logic dominates decision-making situations where regulations and norms are not aligned. This finding has not been observed in previous studies of cases where regulations and norms are not aligned (e.g., Greenwood et al. 2010). In fact, this study shows that cognitions consistently overrule norms and regulations in venture support, which is an interesting finding for a study of government decision makers. The empirical results identify four overshadowing forces that mitigate and compensate for the regulative and normative influences on financing decisions. These findings extend existing research in this area of GVCs' decision making by Thornton et al. (2012), Greenwood et al. (2011), and Scott (2014), forming the basis of what we call the cognitive overshadowing effects in venture funding decisions. We discuss the implications of our research for GVC practice.

\section{Theoretical background}

\subsection{Contextualizing government venture capitalists' decision making}

GVCs have specific differences from traditional welldocumented venture capitalists. GVCs play a role in financing ventures that are not secure enough to acquire bank loans. GVCs thus provide funding at a relatively low capital cost to ventures that may not yet be able to secure funding from traditional venture capitalists (Colombo et al. 2016; Gorman et al. 2005). Examples of ventures that may be supported by GVCs include new or innovative ventures facing particularly high uncertainties or with less obvious potential for return on investment (ROI; Block et al. 2018; Croce et al. 2018; Luukkonen et al. 2013). Another important difference is that GVCs' support for ventures may serve certain political goals by, for instance, strengthening important sectors that rely on government interventions and that lack access to finance from free markets and venture capital (Bertoni and Tykvová 2015; Clarysse et al. 2007; Colombo et al. 2016). Accordingly, when ventures are aligned with certain political goals, GVCs are willing to take higher risks, and they lower their ROI requirements with respect to other types of financiers (e.g. banks). Consequently, GVCs do not operate under the single measure of ROI, which is a core form of macro logic in traditional financial markets, particularly venture capital (Croce et al. 2018; Colombo et al. 2016; Davis 2009; Luukkonen et al. 2013; Zajac and Westphal 2004).

Perhaps the most noteworthy difference in this realm is how venture capital distributions are regulated. GVC is derived from supranational or national sources and depends on political will and taxation for its existence (Colombo et al. 2016). This scenario creates major complexity and imposes substantial constraints on decision making. For example, the government funding of this study derives from both national and European Commission sources of funding. Accordingly, financiers' investment decisions are regulated by international laws and legislations. In performing this investment decision, these financing bodies must comply with multiple political macro logics, including those of the European Commission, national, regional, and local municipality regulations, and political directives. A further complicating factor is that these regulations and political directives are subject to constant change between and during government administrations. Each level of the regulations and political directives contains multiple macro logics, including concerns for the environment, society, and quality of life. Ventures are intended to contribute to developing an attractive area in which to live, increasing employment rates, and aiding innovation and business growth (Colombo et al. 2016). All of these factors imply that the financing decisions of GVCs 
require the balancing of political targets, policy aims, alternatives, and venture potential.

This study builds on existing research on traditional venture capital that focuses on how venture capitalists assess investment potential (Drover et al. (2017). Early research on venture capitalists showed that they use a wide range of factors when evaluating business potential (Gompers et al. 2009). More recent research has provided a more nuanced view of decision making beyond rational formulas and rigid approaches, looking into the subjective and interactive nature of venture capital decision making (Kirsch et al. 2009; Petty and Gruber 2011). Scholars have proposed cognitions and the multifaceted and contingent nature of decisions as promising areas to advance the venture capital literature (Drover et al. 2017; Malmström et al. 2017) and go beyond the obvious. Studies have shown that venture capitalists are unaware of their decision making; self-retrospection is a difficult task (Sharma 2015). The present study answers calls for knowledge on the organizational behavior and institutional mechanisms underlying venture capitalists' decision making (Petty and Gruber 2011).

\subsection{Institutional influences on government venture capitalists' decision making}

From the contextual background where GVCs make decisions, we acknowledge institutional influences on decision making. Building on Scott's (2014, p. 33) widely used theoretical conceptualization, we view institutions as consisting of regulative, normative, and cognitive logics that give meaning to, constrain, and guide social behavior. The widely used institutional theory enables us to understand organizational phenomena such as subtle and prevalent formal and informal organizational structures (Battilana et al. 2009; Greenwood et al. 2010; Scott 2000). These structures are the rules of the game in the social setting that also affect goals, beliefs, and behavior (Ahlstrom and Bruton 2006; Scott 2014).

The core idea of Scott's (2014) framework is that all institutions have a formal regulative influence that regulates, shapes, and constrains behavior. This regulative influence is based on well-defined social obligations and taken-for-granted assumptions concerning social realities (Judge et al. 2008). Regulative influence is typically expressed through formal rules and legal sanctions (DiMaggio and Powell 1983; Scott and Davis 2007;
Thornton et al. 2012). The less formal normative influence refers to established policy and professional standards and procedures (Bezemer 2002; Scott 2014). Normative influence determines professional and social obligations and guides behavior that is established socially, thus defining the roles and actions expected of individuals (Johansson 2007; Scott 2014; Scott and Davis 2007; Trevino et al. 2008). Cognitive influence, the most informal influence, reflects cognitions that are shared among individuals such as shared perceptions of what is taken for granted (Busenitz et al. 2000; Scott 2014). Shared cognitions are based on values, cultural rules, and symbols that form social reality, increasing understanding and guiding behavior (Farashahi et al. 2005; Zucker 1977). According to studies of venture capital firms, institutions affect the formation of goals and processes (Wright et al. 1992).

Institutional influences affect organizational members' interpretations and actions. Behavior encompasses a coherent set of assumptions and values that are deeply embedded in actors' cognitions and preferences. It defines what is perceived as meaningful and appropriate in decision-making situations (Tolbert et al. 2011). Recent studies have begun to explore cognitive, normative, and regulative influences due to pressure from internal and external conditions and to study how such pressure affects organizational behavior (Biniari et al. 2015; Souitaris et al. 2012). Scholars studying how to deal with institutional influences and face conflicting institutional pressures have shown that rules and norms attached to such conflicting pressures constrain and regulate while also empowering innovation and enabling strategic use of different institutional demands (Thornton et al. 2012).

This study reveals specific insights into cognitive influence in a complex, incongruent decision-making environment where the above-mentioned institutional forces are non-aligned. Being non-aligned implies that regulative, normative, and cognitive influences may push a decision in different direction with different forces. Striving to act rationally requires a balancing act when regulation and norms are non-aligned (Thornton et al. 2012). Based on this view, we examine the investment decisions that GVCs must make to balance competing cognitions, norms, and regulations when assessing ventures and interpreting preferred decision outcomes. Our study shows that investment decisions are difficult for financiers to manage as social beings (Friedland 1991: 258) and that the cognitive 
influence dominates when these logics are non-aligned. These logics are expected to compete in this uncoordinated setting, where financiers are pressured to deal with these incongruences (Binari et al. 2015; Souitaris et al. 2012). Little focus has been placed on the potential dominance of the cognitive logic when actors are pressured by incongruent regulative and normative logics (Greenwood et al. 2011; Lawrence et al. 2011). This study helps explain how using the cognitive influence enables financiers to interpret uncertain, complex investment decisions by guiding their behavior and paying less attention to other non-aligned institutional influences. Although this issue has not been previously discussed in the institutional literature, other authors have shown that actors' behaviors are bounded by cognitive limits on attention (Simon and Barnard 1947; Ocasio 1997) and cognitive heuristics in decision making (Kahneman 2003; Kahneman et al. 1982). Thus, the present study provides further conceptual development and offers new insights into such strategies when navigating venture investment decisions. In outlining how cognitive influence underpins investment decisions, we show how the cognitive logic dominates the regulative and normative logics.

\section{Research method}

\subsection{Sample approach}

We use an embedded longitudinal case study (Eisenhardt 1989a, 1989b; Hallen and Eisenhardt 2012) of GVCs to understand the institutional logics of venture capitalists' organizational decision making in general and GVCs in particular, this in relation to decisions on ventures' funding applications. The GVC industry provides an attractive entrepreneurial finance scenario to study institutional mechanisms and organizational behavior. First, government financiers fill a critical gap in the financial market for new and innovative ventures and act as catalysts of regional economic development (Bertoni and Tykvová 2015; Zhang 2018). Second, the investment decision making is embedded in a highly regulated context where the use of taxpayers' money means that the distribution of resources is expected to be efficient. Third, the decision makers are experienced and competent in financial decision making.
Our sample draws on data derived from observing a group of GVCs who made investment decisions after assessing multiple investment proposals - specifically, for ventures seeking government financing. The selected case is a Swedish GVC organization that finances small and medium-sized ventures to foster innovation and business growth. The government organization is nationally anchored with subunits in regions around the country. The general regulations are the same for all subunits, where the regulations are linked to the specific type of venture capital fund. Therefore, the subunits operate geographically near the market and the ventures they assess. The financiers in this study are passive investors who do not actively intervene in the companies they finance. In contrast, traditional venture capital firms typically devote considerable management resources to coaching ventures (Petersen and Rajan 1995). The GVCs' investment goals are both governmental and financial (cf. Block et al. 2018), whereas traditional venture capitalists primarily focus on financial goals. Furthermore, GVCs' financial goals do not primarily focus on ROI, whereas ROI is critical for venture capital funding.

The amount of funding distributed nationwide during the observed period was approximately $€ 190$ million. The informants belonged to one of the regional offices. We gathered data from seven GVC officers: two women and five men. The average age was 54 years. All had university degrees, mostly in business and finance. The group's average length of occupational experience was 17 years. The most experienced officer had worked at the organization for 25 years, whereas the least experienced officer had worked there for 2 years. The average annual amount of funding available for allocation by this specific regional group is $€ 10$ million.

Final investment decisions (i.e., the decision to approve or reject venture applications) were made in decision meetings where the whole group of GVC officers took part. Previous research on venture capitalists has focused on the screening phase and the post-investment phase. There is a lack of studies of the context where the final formal decision is made. This GVC organization welcomed us into their decision meetings, providing access to longitudinal observations of the officers' investment decision-making processes. We took part in nine decision meetings. Scholars have called for realtime research to capture venture capitalists' decision making and deal with self-rationalization bias. This study of real-time observations based on actual decision 
situations complements previous studies of venture capitalists' decision making primarily using post hoc methods and studies using real-time methods such as protocol and conjoint analyses typically based on experimental or tentative situations (Sharma 2015; Silva 2004). The final decision meetings provided the unit of analysis.

GVCs are generalists who typically assess and make decisions about ventures in different industries using less-detailed and -in-depth analyses than specialists. The venture applications that the GVC officers assessed in this study included ventures that operated in different industries, requested various amounts of funding, and varied considerably in the estimated size of their potential market, product, management credibility, degree of innovation, geographical location, and business model. Variations of this kind are useful in validating an accurate, relevant, reasonable, and generalizable theory (Hallen and Eisenhardt 2012). In the decision meetings where the venture applications were assessed, the applications were either approved or rejected. In total, 125 decisions were taken.

The decision meetings took place as follows. One GVC officer was in charge of each venture proposal. That officer collected information on the venture, talked to key people in the venture organization, held discussions with people in the GVC-officers' network and with people internally in the GVC organization, and carried out analyses. The officer in charge of the application also presented the case to colleagues. A decision was reached in a decision meeting where all seven financiers were actively involved in the decision and actively participated in conversations during the meeting.

\subsection{Data collection}

We studied 125 funding decisions. Observations on these decisions were made by a group of researchers, resulting in $36 \mathrm{~h}$ of pure decision observation time and 105 single-spaced pages of transcriptions. All discussions were held in closed-door meetings. This quantity of data increased the potential to identify fragmented and complex patterns when assessing venture applications and to shed light on the institutional logics used in the financiers' decisions (cf. Mezias and Scarselletta 1994). The process continued until a sufficient number of embedded cases had been observed and the data set was considered large enough to meet the aims of the study. Thus, we continued to observe decisions until a saturation point was reached and patterns were clear and validated (Yin 1994).

We addressed potential informant biases in several ways. First, by taking part in meetings over 2 years, we became close to the insiders. The financiers became used to our presence and took no particular notice of us during their discussions. Second, retrospection and rationalization bias were avoided because the observations were carried out in situ in a real-world setting. Third, we triangulated observations with follow-up interviews with the GVC officers, and courtroom questions were asked in reference to actions observed in the decision meetings. Thus, we recorded what the speaker said and did, and we observed what others did in response (cf. Hallen and Eisenhardt 2012).

\subsection{Data analysis}

We used an established three-step coding procedure to identify the decision making of the GVCs, iteratively moving back and forth between qualitative data and emerging theoretical structures (Tavory and Timmermans 2014; Pratt et al. 2006). In the first-order coding, we manually coded the transcribed data. This initial coding was inspired by Strauss and Corbin's (1990) grounded theory approach, in which the stories and statements used during the meetings and the background documentation used for financing decisions were scanned. We searched for statements and expressions associated with a set of guiding questions that helped us make sense of the data. Sample questions included "What was the rationale for the decision?" and "What were the main arguments presented in the investment decision?" In the next step, coding was discussed by the research group. We held recurring meetings to match individual researchers' coding structures, with a focus on groups of five to ten stories at a time. In doing so, we noted very high consistency, which in our view, strengthened the internal validity of the research (Gibbert et al. 2008). At this stage, we observed that the dialogs concerned the market, product and production, finances, and human capital, mirroring the issues identified in the traditional venture capital literature (e.g., Gompers et al. 2005; Knockaert et al. 2010; Muzyka, Sharma 2015; 
Zacharakis and Shepherd 2001). ${ }^{1}$ Tables 1 and 2 provide descriptive data on the official justifications for approving or rejecting applications in accordance with these discussion and decision dialogs.

In the second-order coding process, we grouped the discussions and data related to the first-order codes into categories and more abstract themes about what influenced the investment decision making. At this stage, we found that the observations and decision influences could be understood through Scott's (2014) work on institutions and that this understanding could be elaborated upon by integrating the literature on conflicting institutional influences of regulations, norms, and cognitions (Thornton et al. 2012). The institutional influences we observed were typically non-aligned, creating complexity that financiers must overcome when reaching investment decisions on how taxpayers' money should be distributed (Greenwood et al. 2011; Lawrence et al. 2011). Thus, the in-depth analysis of the institutional influences of regulations, norms, and cognitions on investment decisions was conducted using coding and interpreted through the lens of institutional theory. The coding of the discussions and the justifications for the decisions were based on Denzin and Lincoln's (2011) approach of identifying three institutional influences: regulative, normative, and cognitive. In the analysis, therefore, these three institutional logics were used as categories to classify the discussions that we observed in accordance with a content analysis approach. When reviewing patterns from the secondorder coding, we looked for relationships, leading to the overarching third-order categorization. In this coding stage, we observed that the institutional influences we identified and focused on could drive either approval or rejection, and we used the three logics (regulative, normative, and cognitive) to differentiate patterns in terms of what actually influenced the decision of whether to approve or reject applications. Consequently, we coded the presence or absence of all institutional influences for each decision in the data set. We coded the influence associated with each one of the regular, normative, and

\footnotetext{
${ }^{1}$ Key assessment indicators in the venture capital literature: (1) market/competitive conditions (e.g., marketing, sales, distribution systems, market dominance, customer segments, competition, and competitors' products); (2) Product/service characteristics and attractiveness and production issues (e.g., design, technology, business potential, production capacity, order processing, and organizational structure and facilities); (3) Human capital (e.g., entrepreneur/management team/core people, capabilities, and potential); and (4) Financial (e.g., future potential and ROI).
}

cognitive institutions as positive or negative based on the following reasoning: if all financiers attached positive values, the specific institutional influence was satisfied and was coded as +2 ; if some financiers attached positive values, the influence was satisfied and was coded as +1 ; if all financiers attached negative values, the influence was not satisfied and was coded as -2 ; if some financiers attached negative values, the influence was not satisfied and was coded as - 1 ; finally, if a form of influence was not present in the discourse, it was coded as 0 .

Based on this coding through the lens of institutional theory, our theoretical conceptualization offers insights into the dominance of the cognitive logic that we observed in this highly uncertain and complex setting. We also coded the discourses associated with cognitive logic and identified four forces reflecting the essence of cognitive logic: (1) initial perspective, (2) expression of positive/negative feelings, (3) cognitive identity restriction, and (4) multiple-perspective validation. As a final step, we conceptually developed a more abstract overarching dimension arising from the patterns and relationships identified in the third-order conceptualization, explaining the dominance of the cognitive logic. At this stage, we used the conceptualization from cognitive dissonance theory (Festinger 1957) as an interpretative framework to further conceptualize the dominance of the cognitive logic in government financiers' investment decisions. We discuss this point further in the last part of our findings.

\section{Empirical results}

\subsection{Using institutional influences to understand government venture capitalists' decision making}

From our observations and interviews, we noted how the GVC officers relied on three interdependent institutional influences that guided their discussions and decision making. Consistent with the work of Scott (2014), we observed how the three types of influences (regulative, normative, and cognitive) guided the GVC officers' financing decisions. Table 3 provides examples of the three institutional influences that guided GVC officers' decision making regarding the key assessment indicators of the market, production, finances, and human capital (Table 4). 
Table 1 Discussions/justification for approval of applications

\begin{tabular}{llr}
\hline Key assessment indicators & Official approval justification & Percentage of applications \\
\hline Market/product/production & New or refined products/services & 29.0 \\
& New markets or increased export & 17.3 \\
& New technology solutions & 5.1 \\
& Prioritized industry & 6.7 \\
& Service in rural areas & 5.1 \\
Sum of market/product/production & Service industry & 1.8 \\
Financial & - & $\mathbf{6 5 . 0}$ \\
Human capital & Establishment of new entrepreneur & $\mathbf{2 9}$ \\
& New entrepreneur in new industries & 1.7 \\
Sum of human capital & Education quality, environment, or organizational development & 3.9 \\
\hline
\end{tabular}

Bold entries presented the distribution of justifications among all rejects and all approvals respectively

Regulative influence was always present because the financiers worked in a highly regulated environment, constrained by both national and international legislation and regulations (national laws, European Commission regulations, and national regulations of government authorities). The regulative influence on GVCs' investment decisions was based on an external orientation and the legal sanctions that they used to justify the decision outcomes. In their discussions of applications when nearing a decision, the financiers commonly asked, "What does the regulation say?" There were various restrictions on finance, the amount of finance available for allocation, and the time frame for receiving funds. As one GVC-officer reported, "There is no ambiguity when looking into the regulations. We are not allowed to support applications that have a competitive distorting effect." Regulative influence was also the most explicit influence because it could be identified not only through

Table 2 Discussions/justifications for rejection of applications

\begin{tabular}{llr}
\hline Key assessment indicators & Official dismissal justification & Percentage of applications \\
\hline General & Incomplete application & 0.8 \\
& Withdrawn application & 15.7 \\
Sum of general & & $\mathbf{1 6 . 5}$ \\
Market/product/production & No clear business concept & 2.5 \\
& Competitive distorted effect & 29.5 \\
& Lack of market-related conditions & 4.9 \\
Sum of market/product/production & Not a supported industry & 23.0 \\
Financial & & $\mathbf{5 9 . 9}$ \\
& Other funding has been provided & 1.6 \\
& Not financially viable & 0.8 \\
Investment can be made without support & 4.1 \\
Sum of financial & Non-profitable business & 0.8 \\
Human capital & Debt account at the enforcement authorities & 0.8
\end{tabular}

Bold entries presented the distribution of justifications among all rejects and all approvals respectively 
Table 3 Government venture capitalists' decision-making and use of key assessment indicators in the institutional system

\begin{tabular}{|c|c|c|c|}
\hline \multirow{2}{*}{$\begin{array}{l}\text { Key } \\
\text { assessment } \\
\text { indicators }\end{array}$} & \multicolumn{3}{|l|}{ Institutional systems } \\
\hline & Regulative system & Normative system & Cognitive system \\
\hline $\begin{array}{l}\text { Market, } \\
\text { product } \\
\text { and } \\
\text { produc- } \\
\text { tion }\end{array}$ & $\begin{array}{l}\text { o Prioritized/supportable industries } \\
\text { - Type of companies to support } \\
\text { o Supportable/prioritized geographi- } \\
\text { cal area } \\
\text { o New markets, increased export } \\
\text { o New technology solutions } \\
\text { o New or refined products/services } \\
\text { - Clarity of business concept } \\
\text { - Competitive distortion effect } \\
\text { o Market conditions }\end{array}$ & $\begin{array}{l}\text { Own norms among the group of } \\
\text { financiers (e.g., on businesses, support } \\
\text { areas, unique products, market } \\
\text { characteristics, and competition). } \\
\text { Ethical aspects of the funding. (e.g., } \\
\text { entertainment machinery in tourism) } \\
\text { Although not mentioned in regulation, } \\
\text { supportive of businesses that } \\
\text { collaborate with large national } \\
\text { cooperation contributing to social } \\
\text { development }\end{array}$ & $\begin{array}{l}\text { Own subjective evaluation of the } \\
\text { market, product, and production } \\
\text { potentials } \\
\text { Own preferences. Some more favored } \\
\text { than others } \\
\text { Taken-for-granted assumptions not } \\
\text { shared by regulation or group }\end{array}$ \\
\hline $\begin{array}{l}\text { Human } \\
\text { capital }\end{array}$ & $\begin{array}{l}\circ \text { Be legally competent } \\
\circ \text { No payment defaults } \\
\circ \text { Disqualified for running own } \\
\text { business } \\
\circ \text { Increase of employment rate } \\
\circ \text { Educational investments (quality, } \\
\text { environment, or organizational } \\
\text { development) } \\
\text { New establishment of entrepreneur } \\
\text { New entrepreneur in new } \\
\text { industries }\end{array}$ & $\begin{array}{l}\text { Norms on what is relevant } \\
\text { (entrepreneurial characteristics, } \\
\text { education, experiences, and social } \\
\text { network). Entrepreneur's track record }\end{array}$ & $\begin{array}{l}\text { Individual subjective definitions of } \\
\text { entrepreneurs' and key people's } \\
\text { characteristics that are not shared or } \\
\text { mentioned in regulation or group norms } \\
\text { Analogies between situations that are } \\
\text { used for decision-making argumenta- } \\
\text { tion }\end{array}$ \\
\hline Financial & $\begin{array}{l}\text { Scope of support clear limits (e.g., } \\
20 \%-50 \% \text { of the applicant's } \\
\text { investment). Substantial financial } \\
\text { effects of investment } \\
\text { o Regulations on the companies' } \\
\text { financial situation } \\
\text { O Not bankruptcy } \\
\text { O Unable to self-finance the whole } \\
\text { investment } \\
\text { O Profitability of business } \\
\text { D Degree of earlier public funding }\end{array}$ & $\begin{array}{l}\text { Group norms on scope depending on } \\
\text { particular characterized situations } \\
\text { Group norms for interpreting the } \\
\text { substantial financial effects of } \\
\text { investments } \\
\text { Norms for what is acceptable counter } \\
\text { financing }\end{array}$ & $\begin{array}{l}\text { O Subjective perceptions of the scope of } \\
\text { investment; how much to support } \\
\text { Subjective expectations on future } \\
\text { financial performance, in comparison to } \\
\text { prior own experiences (e.g., of industry } \\
\text { performance) }\end{array}$ \\
\hline
\end{tabular}

discussions but also through website resources, written laws, and standardized application forms. When considering a decision, the financiers often checked and recalled explicit material. As one of the financiers stated, "Let's make sure that this is in line with the rules and application requirements; regulations only support new investments and not the maintenance of old equipment."

We found support for the normative influence because we observed that the financiers had established strong norms and policies over the many years they had worked together. This situation was evident in statements such as "We have always followed this reasoning." Norms and policies were typically expressed via explicit written guidelines specified by the group and via explicit and implicit or tacit verbal discussions. An example of such a norm is a decision situation described by one financier as follows: "Our written guideline on machinery in tourism is to support eco-friendly investments." Nevertheless, re-evaluating the policies and norms was invariably an item on the regular meeting agenda. The financiers discussed specific and explicit policies and norms and subsequently changed, refined, or confirmed them. The financiers related specific venture applications to their established norms and policies. Common expressions included "What is our policy regarding this?" and "Our policy is not to support this type of business." This evidence reflects the financiers' normatively governed justifications of decision outcomes. The group often discussed what they could or could not do and how they were expected to act 


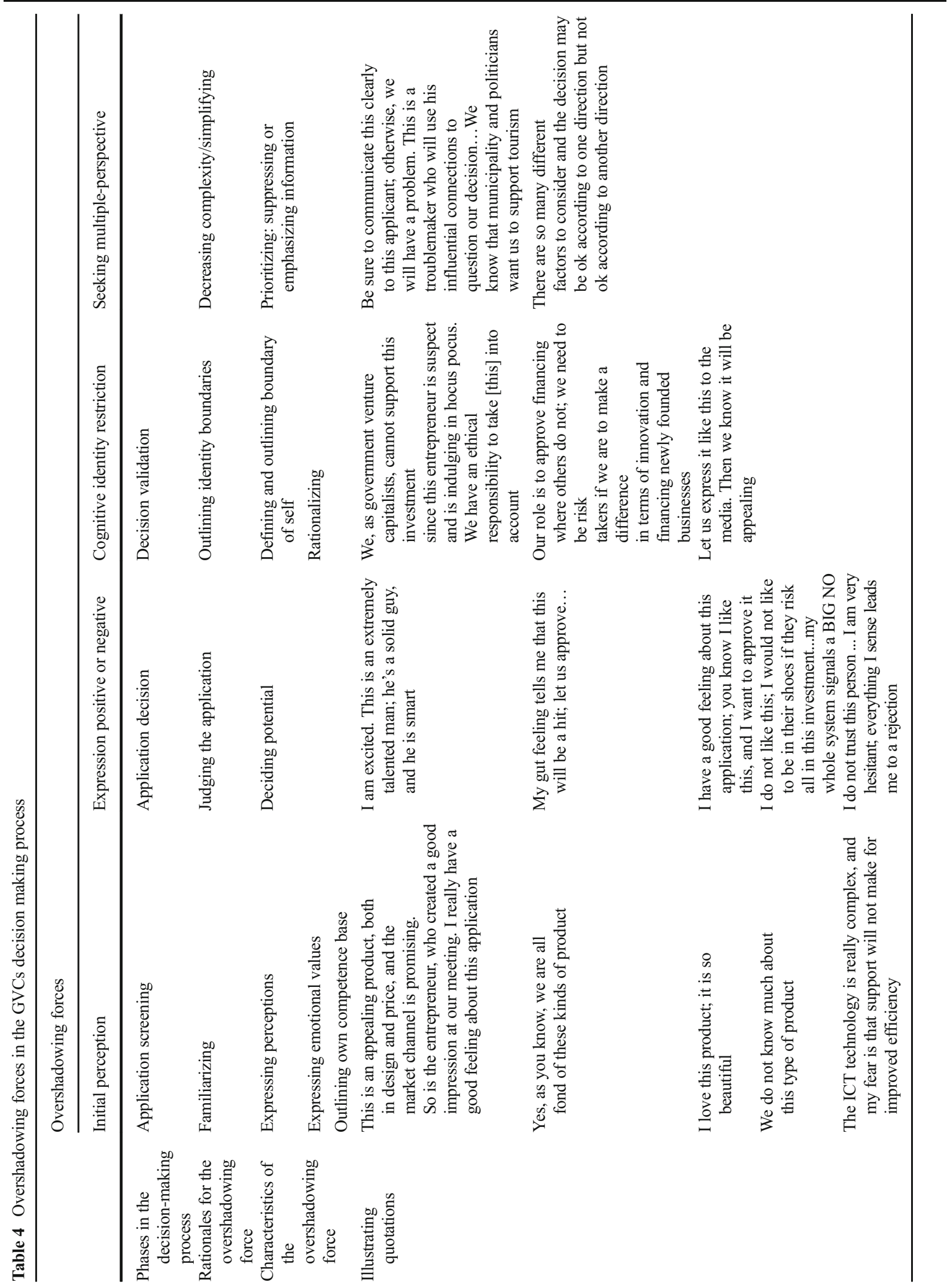


according to norms. Statements such as "All tourism ventures can't have a full machinery park; we stipulate that we want them to cooperate" were common during the discussions.

Finally, we observed that the cognitive influence was important in investment decisions. Cognitive influence was expressed verbally in the financiers' discussions, and cognitive guidance had both an outspoken explicit character and a less outspoken tacit character. The financiers often drew analogies with earlier situations, asking themselves questions such as "How did we respond before in a similar situation?" or "In the case of venture $X$, we dealt with it by..." The group often referred to feelings and emotions in the investment decisions: "I have a good feeling about this product. It is so beautiful," "I don't like this...," or "I don't trust this person." These examples illustrate the taken-forgranted, shared understanding, and the subjectively agreed-upon criteria within the group, expressed through analogies, feelings, emotions, and beliefs (i.e., based on compliance). Cognitive influence is based on an internal orientation. The financiers discussed applications with varying degrees of passion, and their body language helped express feelings of dislike or excitement. For example, when the financiers had difficulty understanding the product or the entrepreneur and displayed a negative bias toward the application, we sometimes heard statements such as "this entrepreneur is suspect and is indulging in hocus pocus." On such occasions, the discussions revolved around the location of the business or the reputation of the entrepreneur, particularly when linked to previous poor performance, which encouraged financiers to reject the application. The examples in our observations and interviews suggest that the justifications for decision outcomes were built on what was comprehensible, recognizable, and culturally and emotionally supported. Furthermore, cognitive logic is characterized by bounded rationality or, in some cases, irrationality in investment decisions.

Consistent with the literature on legitimacy in the institutional framework (Scott 2014; Thornton et al. 2012), we found that the investment decisions were subject to all three influences. Regulative influence serves as the basis for or the input of the work, while normative and cognitive influences are used to decide on financing support. It should be noted, however, that the regulative influence was used to justify the final decision outcome but that any signs of the involvement of norms or cognitions were absent from official communications. Interestingly, although all three institutions were present in financiers' investment decisions, cases in which all three institutions supported a decision were rare. This finding somewhat contradicts the traditional understanding of institutional theory in terms of dynamism (DiMaggio and Powell 1983; Scott 2014) and is close to the conceptualization in research on fragmented institutions (Biniari et al. 2015; Friedland 1991; Greenwood et al. 2010; Pache and Santos 2010). By carefully analyzing the impact of the three institutions, we were able to identify meaningful implications regarding the dominance of cognitive institutions, which the institutional theory literature does not fully acknowledge. Thus, we contribute by providing new knowledge on how financial institutions deal with the multiplicity of internal and external pressures by predominantly leaning on cognitive institutions.

Notably, the institutionalized investment decision framework involves all three types of institutions, with the cognitive logic playing a dominant role in guiding investment decision outcomes. Below, we elaborate on these considerations and shed light on the official and unofficial justifications for GVCs' investment decisions.

4.2 The importance of the cognitive logic and the presence of overshadowing forces

We observed that cognitive institutions substantially influenced the way in which the decision making was institutionalized. The cognitive influence underpins the habitual ways of thinking and behaving within a particular organization. This was found to be the case with the funding decisions by the GVCs (see Mouritsen 1994; Sharma 2015). Furthermore, we noted that the cognitive logic affected how complexity in investment decisions was framed and how the financiers, in their discussions prior to investment decisions, found solutions and justified decision outcomes in the absence of clear regulative guidance (Greenwood et al. 2011; Thornton et al. 2012; Lawrence et al. 2011).

In the context of this study, cognitive institutions enabled financiers to orient their investment decisions with a degree of assurance when facing multiple macro logics. The GVCs often turned to bounded rationality when relying on these multiple macro logics to assess information and make decisions (Gabrielsson and Huse 2002). Certain decisions were somewhat irrational given the major influence of the cognitive logic. We noted that bounded rational-irrational cognitive frameworks were 
involved at critical decision points. These frameworks helped financiers make more balanced decisions, ultimately reaching decisions where the regulative and normative logics were not satisfied or where the logics conflicted. The financiers could thus act flexibly and renegotiate their behavior from situation to situation (e.g., depending on the pressure and direction for legitimation needed for instance internal or external pressure or legitimation).

We assessed how much time the financiers spent discussing important information and how the three institutional influences interacted. During these investment decisions, GVCs discussed the key assessment indicators: markets, production, and products (83\% of the content), human capital (10\% of the content), and financial and investment information (7\% of the content). Previous studies of traditional venture capitalists have shown that the financial and investment information and human capital are the most critical assessment indicators and that venture capitalists focus on what can be measured (Hall and Hofer 1993). GVCs use the same type of assessment indicators as traditional venture capitalists, although they rely less on measurable criteria. The venture capital literature has moved away from the mere identification of assessment indicators. We follow this trend by further examining the behavioral aspects of decision making. The structure of the assessment indicators clearly relates to the imperative to legitimize decisions; indeed, financiers' decisions are legitimized to the extent that they conform to the existing basis of compliance (Scott and Davis 2007; Trevino et al. 2008). Such legitimatization is consistent with institutionalized investment decisions (Gorman et al. 2005; MacMillan et al. 1985). The discussions that focused on whether to approve an application showed that the cognitive logic played a crucial role in investment decisions. We observed that $47 \%$ of discussions were associated with the cognitive logic, $16 \%$ with the normative logic, and $14 \%$ with the regulative logic. We also observed that the cognitive logic appeared to be built on the four overshadowing forces presented below, allowing it to dominate in the investment decisions. In our view, the four overshadowing forces ensured the dominance of the cognitive logic when the institutional logics, including the normative and regulative logics, were non-aligned.

First, formulating what we labeled the initial perspective to assess the venture application allowed the financiers to familiarize themselves with each venture and each application. This is the deal originating phase in Silva's (2004) study of venture capital decision making. The financiers in this phase used the cognitive logic to assess venture information so that they could comprehend the venture, the investment, and the effects of the investment (cf. Baum and Silverman 2004). The cognitive logic is important early in the investment decision. This phase emphasizes the GVCs' perceptions, emotional values, and lack of competence in relation to, for example, products, markets, and regulations. Statements such as the following illustrate this point:

This is an appealing product, both in design and price, and the market channel is promising. So is the entrepreneur, who created a good impression at our meeting. I really have a good feeling about this application.

Yes, as you know, we are all fond of these kinds of products.

The converse is also true, as reflected by statements such as the following:

We don't know much about this type of product. The ICT technology is really complex, and my fear is that support will not make for improved efficiency.

Doesn't this product function like wiretapping and societal control? We do not want to be part of such activities. How can we get out of this one? What regulation can we turn to?

These statements suggest that the financiers' initial perspective also influenced the use of regulative and normative logics. Overall, initial learning about a venture and forming an initial perspective laid the foundations for the financiers to use the other institutional logics to make a decision. This initial use of the cognitive logic outlines dominance of cognitive logic.

By making sense of key assessment indicators and attributes when processing venture applications, the financiers fashioned a social perception that produced a collective image of the venture. This social perception also helped them evaluate the venture's potential fit with the multiple macro logics that the financiers used, thus widening the scope for funding approval. In many cases, the financiers spent considerable time (up to 98\%) developing 
a collective image and evaluating the venture's potential. Overall, forming the initial perspective proved important for the ultimate financing decision because it oriented the financiers' thinking toward the use of the regulative and normative logics. This was an overshadowing force because in cases where the initial perspective conflicted with other logics, it was the initial perspective that determined whether financial support was granted.

Second, what we categorized as expressions of positive or negative feelings regarding venture attributes were part of the cognitive logic guiding the investment decision. This phase corresponded to the deal evaluation phase where judgment of the application took place and where the GVCs determined the investment potential (cf. Silva 2004). Like Cardon et al. (2009), we found that the financiers often based their evaluations on their passion for a venture application. Positive feelings about the products and the entrepreneurs were advantageous for ventures in securing funding. This phase highlighted stereotypical expressions of what was considered "right" and "wrong." GVCs showed overconfidence in investments due to emotions. This was expressed in statements such as the following:

I am excited. This is an extremely talented man; he's a solid guy, and he is smart.

The entire team expressed approval. Other statements reiterated the role of positive feelings:

I have a good feeling about this application; you know I like this, and I want to approve it.

My gut feeling tells me that this will be a hit; let's approve...

The group often referred to negative feelings and emotions in investment decisions:

I don't like this; I would not like to be in their shoes if they risk all in this investment...my whole system signals a BIG NO.

I don't trust this person ... I am very hesitant; everything I sense leads me to a rejection.

Although limited time (between 20 and $30 \%$ of the discussions) was devoted to expressing emotions, such expressions based on the cognitive logic had a substantial influence on decision outcomes when they were verbalized. The use of both normative and regulative logics was influenced by such expressions. In fact, when feelings were expressed, discussions often took new directions. Several cases were observed in which expressing positive feelings ran counter to the regulative logic but nevertheless received support upon revising the normative logic. Such behavior caused inconsistency in the GVCs' decision making (cf. Dimov et al. 2007)

Third, financiers' confirmation of themselves, including their cognitive and social identity (e.g., being government representatives with their attendant responsibilities) and what we refer to as financiers' cognitive identity restriction guided investment decisions based on financiers' pre-existing value judgments of what can be financed (Ashforth and Mael 1989; March and Olsen 1989; Thornton et al. 2012). This behavior refers to the deal closing phase (cf. Silva 2004) involving rationalization of the decision. The financiers in this phase often voiced reputational concerns in relation to their roles as GVC officers, their professional functions, and their codes of conduct. Concerns of own reputation were evident when the GVCs initiated their discussions with statements such as the following:

We, as government venture capitalists can't support this investment since this entrepreneur is suspect and is indulging in hocus pocus. We have an ethical responsibility to take [this] into account.

Our role is to approve financing where others do not; we need to be risk takers if we are to make a difference in terms of innovation and financing newly founded businesses.

Given this cognitive identity restriction, the GVCs discussed what they could or could not do and how they were expected to act according to their roles (e.g., their authority). Although only $9 \%$ of the discussions related to this overshadowing force, it influenced their behavior substantially when making their investment decisions and discussing the granting of financial approval.

Fourth, the cognitive logic was used to formulate decisions through what we call multiple-perspective validation. This phase was also part of deal closing. It refers to finding links between the financiers' own knowledge and how the financiers perceived the 
external expectations of multiple stakeholders such as venture applicants, the media, municipalities, and politicians. This phase involved simplifying complex situations, suppressing information that did not support the decision, and emphasizing information that did support the decision. The GVC officers dealt with high complexity and high uncertainty due to conflicting expectations and conflicting goals. The financiers developed techniques to respond cognitively to macro logics while legitimizing and rationalizing their investment decisions. Statements such as the following support this point:

Let's express it like this to the media. Then we know it will be appealing.

Be sure to communicate this clearly to this applicant; otherwise, we will have a problem. This is a troublemaker who will use his influential connections to question our decision... We know that the municipality and politicians want us to support tourism.

Our data show that this multiple-perspective validation influenced the prospect of approving finance for entrepreneurial endeavors. The financiers appeared to use their bank contacts, the media, and politicians to test their perspectives on how best to legitimize their investment decisions. Although this overshadowing force was subtle, the multiple-perspective validation not only removed some of the uncertainty but also made the work appear rational (Scott 2014). We observed that $15 \%$ of the discussions touched on the multiple-perspective validation, and our observations support the importance of this kind of discussion in influencing decisions concerning venture capital approval. Again, these observations support the prominent role of the cognitive logic.

\section{Discussion and conclusions}

The study of 125 funding decisions reveals that the cognitive logic serves as a dominant logic for assessing proposals and allocating finance. This dominance is evident when financing is allocated based on the cognitive logic, and the regulative and normative logics are absent. The relative dominance of cognitive logic is shown through the four overshadowing forces of (1) initial perspective, (2) expression of positive or negative feelings, (3) cognitive identity restriction, and (4) multiple-perspective validation. The dominance of the cognitive logic through these overshadowing forces can be linked to cognitive consonance and cognitive dissonance (Festinger 1957; Shultz and Lepper 1996). Satisfying the cognitive logic could be interpreted as cognitive consonance - that is, perceiving a fit between the institutionalized image of an approvable venture application and the venture application at hand. In contrast, failing to satisfy the cognitive logic could be seen as cognitive dissonance - that is, perceiving a lack of fit between the institutionalized image of an approvable venture application and the venture application at hand.

In Fig. 1, we illustrate how the four overshadowing forces correspond to different stages of finance decision making and influence other logics. During the first stage (application screening), the financiers read, shortlisted, and ranked the applications. During this decision stage, GVCs were highly influenced by the cognitive logic leading to an initial perception of the applications. For example, during the screening of a successful application, the financiers familiarized themselves with and made sense of the applicant's financial status, the industry, and the social network. The positive initial perception led to expressing positive feelings about the business concept. However, the financiers largely overlooked regulative and normative logics. Issues such as the regulations governing what to finance and the interpretation that the business had low economic growth potential were not critically considered as part of the initial assessment.

The next decision phase focused on the application decision, during which the financiers voted whether to approve or reject the applications. As in the previous phase, the cognitive logic influenced the expression of positive or negative feelings about the application. The overshadowing force of the cognitive logic came across in meetings through the use of strong words and motivations that were meant to justify the underuse of the other logics. The final phase of decision validation was where the financiers justified their decisions internally and externally to diverse stakeholders such as the entrepreneurs, the public, and the media. During this stage, the forces of cognitive identity restriction and seeking multiple-perspective validation were dominant. Expressing cognitive identity restrictions was also used by the GVCs to reinforce their own position as governmental officers in certain meetings. Another example is 
Fig. 1 Importance of the cognitive logic and the presence of overshadowing forces

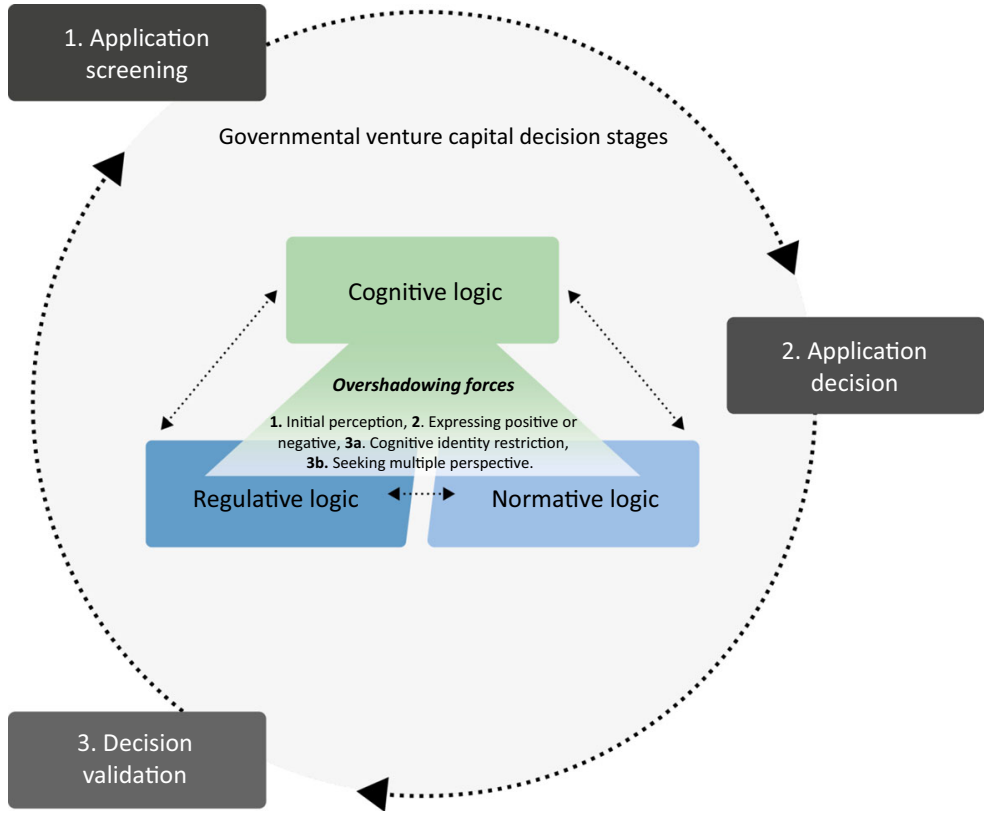

financiers' use of multiple-perspective validation when referring to an external municipality organization and to media reactions to the decision. Normative and regulative logics such as validating decisions in accordance with stipulated regulations or norms on how to navigate decision outcomes between complementary or conflicting assessment indicators were largely conducted based on individual financiers' attempts to apply their internal identity restrictions and seek multiple-perspective approval. Thus, the four overshadowing forces facilitate the decision outcome, illustrate the dominance of the cognitive logic, and show how financiers arrive at cognitive consonance even with or without the influence of the normative and regulative logics.

\subsection{Theoretical implications}

Our findings suggest that an institutional framework aids our understanding of the institutional setting and organizational behavior in terms of how GVCs work (DiMaggio and Powell 1991; Douglas et al. 2008; Peng et al. 2009; Scott 2014) and our understanding of the social behavior that takes place in the capital market when government capital is distributed. The findings show that the contradictions between regulations, norms, and individual cognitions should be highlighted. When regulative and normative logics are not satisfied by the application, the cognitive logic tends to dominate
GVCs' decision making. This finding is surprising because of the importance of the regulations that GVCs are supposed to follow in their decision making. The regulative and normative logics serve as the basis for or input to the decision process, but the cognitive logic nonetheless dominates the process and the decision outcomes.

The most substantial contribution of our study to research on behavior in entrepreneurial financing and venture capital decision making relates to the dominance of the cognitive logic in highly complex and incongruent decision environments. Specifically, we contribute to institutional theory, particularly the entrepreneurial finance literature on venture capitalists' decision making, by developing new conceptualizations (i.e., the identification of four overshadowing forces that illuminate how GVCs are able to selectively turn their attention to particular cognitive cues and sway their decisions). Our findings are novel in that they highlight how selective bounded attention shapes the way that problems are framed when searching for solutions. Using selective overshadowing forces allows GVCs to neglect the regulative and normative logics. This finding shows how the cognitive logic overrules other logics in reaching decisions. This paper also shows that relying on the cognitive logic allows for discretionary action and inhibits predictable results. Thus, our research responds to the calls in the institutional logic literature for "a full understanding of the role of social actors in 
shaping and being shaped by institutions requires a more developed theory of human behavior" (Thornton et al. 2012). More contextualized knowledge is needed to understand and enrich "how to interpret organizational reality, what constitutes appropriate behavior, and how to succeed" in an organizational setting (Thornton 2004, p. 70). Thus, we outline heterogeneity in venture capitalists' decision making (i.e., critical differences between GVCs and traditional venture capitalists). Our specific integration of this macro-oriented literature of institutional theory with that of the micro-oriented framework that we developed by drawing upon the work of Scott (2014) yields several insights into how these actors deal with a complex, multi-layered decision environment with competing institutional logics.

Our findings are based on an integration of several ideas from institutional theory, which we also believe to be a contribution in its own right. While the institutional framework developed by Scott (2014) indicates that social behavior is constrained and guided by regulative, normative, and cognitive systems, the literature on institutional logic has a broader scope and acknowledges the institutional logic from macro to micro levels guiding social behavior (Thornton et al. 2012). However, our study provides detailed insights based on observations and interviews, which have been largely lacking in prior studies. By describing stories and events during different phases of the decision-making process, we illustrate the breakdown of how the cognitive overshadowing forces influence rejection or approval decisions in a GVC context. The complexity and dynamics in the decision meetings provide a novel context for studying institutional factors and identifying micro-level insights. We thus offer support for the institutional influences reported in our study. The literature on institutional logic suggests that what is considered the broader institutions and the "principles, practices and symbols of each institutional logic shape how reasoning takes place in assessment work" (Thornton et al. 2012: 2). The main insight of this study is that although social behavior in investment decisions is influenced by multiple macro to micro institutional forms of logic, the cognitive logic dominates in complex, uncertain situations. We thus respond to scholars' calls for knowledge on the interplay between the micro-individual and the mesostructural dynamics of institutional theory.

\subsection{Practical implications}

Although there are limitations regarding the generalization of our findings, the potential dominance of the cognitive logic suggests that entrepreneurs must ensure that financiers not only understand their applications but also perceive how the applications appeal to the cognitive logic. Applicants should understand that the regulative and normative logics do not need to be satisfied. Investors go against these logics, instead relying on cognitions and decision heuristics. This finding is consistent with Grilli and Murtini's findings (2016) that GVCs' investment decisions could be subject to distortions and imperfections (e.g., "pork barrel" spending). Moreover, our study has implications for the general outline of government support for ventures. The literature indicates the need to develop strong institutionalized investment decision routines to reduce decision uncertainty (Gorman et al. 2005; Larson 1977). We enrich this discussion by presenting a framework that shows how institutionalization reduces uncertainty and enables decisions in settings characterized by multiple and contrasting institutional influences. These cognitive influences create a manageable situation for financiers while facilitating a high degree of variation in assessing applications and allowing discretionary decision outcomes. Government support programs for venturing should take note of the multifaceted nature of this situation to enable continuous questioning of habits and deinstitutionalization for healthy re-institutionalization of decision-making behavior (i.e., behavior that make an impact on allocation of resources and performance outcomes).

\subsection{Limitations and future studies}

Our research has several limitations. We encourage future studies to use larger samples of financiers to test our findings. Such studies can assess the reliability and validity of our results and extend knowledge on investment decisions in institutional frameworks. This study observes the dominant institutional logic of cognitions and the occurrence of this logic in multiple situations. A longitudinal study with a larger number of cases may well reveal the pattern of emergence and relative dominance of the cognitive logic over time. Institutional logics are not static; they adapt to social systems and typically evolve over time. Therefore, future longitudinal studies should consider the evolution over longer 
time horizons than the present study considers. Like other scholars, we also advocate exploratory studies that consider institutional theory concerning the circumstances of investment decisions. While our study is limited in number of decision meetings and decisions covered, we hope to encourage researchers to elaborate on this topic. We encourage entrepreneurial finance scholars to expand our understanding of a variety of financial sources by adding to and going beyond traditional venture capital research to better understand highgrowth-potential and innovation financing (Block et al. 2018; Drover et al. 2017). We encourage researchers to develop a nuanced view of decision making beyond the rational formulas and rigid approaches, to dig deeper into the cognitive, multifaceted, contingent nature of financial decision making, and to move beyond the obvious (Kirsch et al. 2009; Petty and Gruber 2011; Sharma 2015).

Funding Information Open access funding provided by Halmstad University.

Open Access This article is distributed under the terms of the Creative Commons Attribution 4.0 International License (http:// creativecommons.org/licenses/by/4.0/), which permits unrestricted use, distribution, and reproduction in any medium, provided you give appropriate credit to the original author(s) and the source, provide a link to the Creative Commons license, and indicate if changes were made.

\section{References}

Abrardi, L., Croce, A., \& Ughetto, E. (2019). The dynamics of switching between governmental and independent venture capitalists: theory and evidence. Small Business Economics, 53(1), 165-188. https://doi.org/10.1007/s11187-018-0047-z.

Ashforth, B. E., \& Mael, F. (1989). Social identity theory and the organization. Academy of Management Review, 14(1), 2039. https://doi.org/10.5465/amr.1989.4278999.

Ahlstrom, D., \& Bruton, G. D. (2006). Venture capital in emerging economies: networks and institutional change. Entrepreneurship Theory and Practice, 30(2), 299-320. https://doi.org/10.1111/j.1540-6520.2006.00122.x.

Battilana, J., Leca, B., \& Boxenbaum, E. (2009). 2 how actors change institutions: Towards a theory of institutional entrepreneurship. Academy of Management Annals, 3(1), 65-107.

Baum, J. A., \& Silverman, B. S. (2004). Picking winners or building them? Alliance, intellectual, and human capital as selection criteria in venture financing and performance of biotechnology startups. Journal of Business Venturing, 19(3), 411-436. https://doi.org/10.1016/S0883-9026(03 00038-7.

Bertoni, F., \& Tykvová, T. (2015). Does governmental venture capital spur invention and innovation? Evidence from young
European biotech companies. Research Policy, 44(4), 925935. https://doi.org/10.1016/j.respol.2015.02.002.

Bertoni, F., Colombo, M. G., \& Quas, A. (2015). The patterns of venture capital investment in Europe. Small Business Economics, 45(3), 543-560.

Bezemer, D. J. (2002). De-collectivization in Czech and Slovak agriculture: an institutional explanation. Journal of Economic Issues, 36(3), 723-745 https://www-jstor-org.proxy.lib.ltu. se/stable/4227819.

Biniari, M. G., Simmons, S. A., Monsen, E. W., \& Moreno, M. P. (2015). The configuration of corporate venturing logics: an integrated resource dependence and institutional perspective. Small Business Economics, 45(2), 351-367. https://doi. org/10.1007/s11187-015-9635-3.

Block, J. H., Colombo, M. G., Cumming, D. J., \& Vismara, S. (2018). New players in entrepreneurial finance and why they are there. Small Business Economics, 50(2), 239-250. https://doi.org/10.1007/s11187-016-9826-6.

Brander, J. A., Du, Q., \& Hellmann, T. (2014). The effects of government-sponsored venture capital: International evidence. Review of Finance. https://doi.org/10.1093 /rof/rfu009.

Busenitz, L. W., Gomez, C., \& Spencer, J. W. (2000). Country institutional profiles: unlocking entrepreneurial phenomena. Academy of Management Journal, 43(5), 994-1003. https://doi.org/10.5465/1556423.

Campbell, J. L. (2004). Institutional change and globalization. Princeton University Press.

Cardon, M. S., Wincent, J., Singh, J., \& Drnovsek, M. (2009). The nature and experience of entrepreneurial passion. Academy of Management Review, 34(3), 511-532. https://doi. org/10.5465/amr.2009.40633190.

Clarysse, B., Wright, M., Lockett, A., Mustar, P., \& Knockaert, M. (2007). Academic spin-offs, formal technology transfer and capital raising. Industrial and Corporate Change, 16(4), 609-640. https://doi.org/10.1093/icc/dtm019.

Colombo, M. G., Cumming, D. J., \& Vismara, S. (2016). Governmental venture capital for innovative young firms. The Journal of Technology Transfer, 41(1), 10-24. https://doi.org/10.1007/s10961-014-9380-9.

Croce, A., Martí, J., \& Reverte, C. (2018). The role of private versus governmental venture capital in fostering job creation during the crisis. Small Business Economics, 1-22. https://doi.org/10.1007/s11187-018-0108-3.

Cumming, D. J., \& MacIntosh, J. (2007). Mutual funds that invest in private equity? An analysis of labour sponsored investment funds. Cambridge Journal of Economics, 31, 445-487.

Cumming, D. J., Grilli, L., \& Murtinu, S. (2017). Governmental and independent venture capital investments in Europe: a firm-level performance analysis. Journal of Corporate Finance, 42, 439-459. https://doi.org/10.1016/j. jcorpfin.2014.10.016.

Cumming, D., \& Johan, S. (2019). Government venture capital research: fake science and bad public policy. Venture Capital, 21 (1), 121-131.https://doi.org/10.1080 /13691066.2019.1562627.

Davis, G. F. (2009). Managed by the markets: how finance reshaped America. Oxford University Press.

Denzin, N. K., \& Lincoln, Y. S. (Eds.). (2011). The sage handbook of qualitative research. Sage. 
DiMaggio, P. J., \& Powell, W. W. (1983). The iron cage revisited: institutional isomorphism and collective rationality in organizational fields. American Sociological Review, 147-160. https://doi.org/10.2307/2095101.

DiMaggio, P., \& Powell, W. (1991). The New Institutionalism in Organizational Analysis University of Chicago Press. Chicago: IL.

Dimov, D., Shepherd, D. A., \& Sutcliffe, K. M. (2007). Requisite expertise, firm reputation, and status in venture capital investment allocation decisions. Journal of Business Venturing, 22(4), 481-502. https://doi.org/10.1016/j. jbusvent.2006.05.001.

Drover, W., Busenitz, L., Matusik, S., Townsend, D., Anglin, A., \& Dushnitsky, G. (2017). A review and road map of entrepreneurial equity financing research: venture capital, corporate venture capital, angel investment, crowdfunding, and accelerators. Journal of Management, 43(6), 1820-1853. https://doi. org/10.1177/0149206317690584.

Eisenhardt, K. M. (1989a). Building theories from case study research. Academy of Management Review, 14(4), 532-550. https://doi.org/10.5465/amr.1989.4308385.

Eisenhardt, K. M. (1989b). Agency theory: an assessment and review. Academy of Management Review, 14(1), 57-74. https://doi.org/10.5465/amr.1989.4279003.

EVCA. (2014). 2013 European private equity activity: statistics on fundraising, investments and divestments. http://www.evca. eu/media/142790/2013-European-Private-Equity-Activity. pdf.

Farashahi, M., Hafsi, T., \& Molz, R. (2005). Institutionalized norms of conducting research and social realities: a research synthesis of empirical works from 1983 to 2002. International Journal of Management Reviews, 7(1), 1-24. https://doi.org/10.1111/j.1468-2370.2005.00104.x.

Festinger, L. (1957). A theory of cognitive dissonance: Stanford Univ Pr. Fornell, C., \& Larcker, DF (1981). Evaluating structural equation models with.

Friedland, R. (1991). Bringing society back in: symbols, practices, and institutional contradictions. The new institutionalism in organizational analysis, 232-263.

Gabrielsson, J., \& Huse, M. (2002). The venture capitalist and the board of directors in SMEs: roles and processes. Venture Capital: An International Journal of Entrepreneurial Finance, 4(2), 125-146. https://doi.org/10.1080 /13691060110094397.

Gibbert, M., Ruigrok, W., \& Wicki, B. (2008). What passes as a rigorous case study? Strategic Management Journal, 29(13), 1465-1474. https://doi.org/10.1002/smj. 722.

Gompers, P., Kovner, A., Lerner, J., \& Scharfstein, D. (2005). Venture capital investment cycles: The role of experience and specialization. Journal of Financial Economics forthcoming.

Gompers, P., Kovner, A., \& Lerner, J. (2009). Specialization and success: evidence from venture capital. Journal of Economics \& Management Strategy, 18(3), 817-844. https://doi.org/10.1111/j.1530-9134.2009.00230.x.

Gorman, G. G., Rosa, P. J., \& Faseruk, A. (2005). Institutional lending to knowledge-based businesses. Journal of Business Venturing, 20(6), 793-819. https://doi.org/10.1016/j. jbusvent.2004.04.002.
Greenwood, R., Díaz, A. M., Li, S. X., \& Lorente, J. C. (2010). The multiplicity of institutional logics and the heterogeneity of organizational responses. Organization Science, 21(2), 521-539. https://doi.org/10.1287/orsc.1090.0453.

Greenwood, R., Raynard, M., Kodeih, F., Micelotta, E. R., \& Lounsbury, M. (2011). Institutional complexity and organizational responses. Academy of Management Annals, 5(1), 317-371. https://doi.org/10.5465/19416520.2011.590299.

Guler, I. (2007). Throwing good money after bad? Political and institutional influences on sequential decision making in the venture capital industry. Administrative Science Quarterly, $52(2), 248-285$.

Hall, J., \& Hofer, C. W. (1993). Venture capitalists' decision criteria in new venture evaluation. Journal of Business Venturing, 8(1), 25-42. https://doi.org/10.1016/0883-9026 (93)90009-T.

Hallen, B. L., \& Eisenhardt, K. M. (2012). Catalyzing strategies and efficient tie formation: how entrepreneurial firms obtain investment ties. Academy of Management Journal, 55(1), 35-70. https://doi.org/10.5465/amj.2009.0620.

Invest Europe (2015). 2014 European private equity activity: statistics on fundraising, investments \& divestments. http://www.investeurope.eu/media/385581/2014europeanprivate-equity-activity-final-v2.pdf. Accessed June 2015.

Johansson, J. (2007). Sell-side analysts' creation of value-key roles and relational capital. Journal of Human Resource Costing \& Accounting, 11(1), 30-52. https://doi. org/10.1108/14013380710746393.

Judge, W. Q., Douglas, T. J., \& Kutan, A. M. (2008). Institutional antecedents of corporate governance legitimacy. Journal of Management, 34(4), 765-785.

Kahneman, D. (2003). A perspective on judgment and choice: mapping bounded rationality. American Psychologist, 58(9), 697. https://doi.org/10.1037/0003-066X.58.9.697.

Kahneman, D., Slovic, S. P., Slovic, P., \& Tversky, A. (Eds.). (1982). Judgment under uncertainty: heuristics and biases. Cambridge University Press.

Kaplan, S. N., \& Lerner, J. (2016). Venture capital data: Opportunities and challenges (no. w22500). National Bureau of Economic Research.

Kirsch, D., Goldfarb, B., \& Gera, A. (2009). Form or substance: the role of business plans in venture capital decision making. Strategic Management Journal, 30(5), 487-515. https://doi. org/10.1002/smj.751.

Knockaert, M., Clarysse, B., \& Wright, M. (2010). The extent and nature of heterogeneity of venture capital selection behaviour in new technology-based firms. $R \& D$ Management, 40(4), 357-371.

Larson, M. S. (1977). The rise of professionalism: a sociological analysis. Berkeley: University of California Press.

Lawrence, T., Suddaby, R., \& Leca, B. (2011). Institutional work: refocusing institutional studies of organization. Journal of Management Inquiry, 20(1), 52-58. https://doi.org/10.1177 $/ 1056492610387222$.

Leleux, B., \& Surlemont, B. (2003). Public versus private venture capital: seeding or crowding out? A pan-European analysis. Journal of Business Venturing, 18(1), 81-104. https://doi. org/10.1016/S0883-9026(01)00078-7. 
Lerner, J. (2002). When bureaucrats meet entrepreneurs: the design of effective public venture capital programmes. The Economic Journal, 112(477), F73-F84.

Lerner, J. (2012). Boulevard of broken dreams: why public efforts to boost entrepreneurship and venture capital have failedand what to do about it. Princeton University Press.

Lerner, J., \& Watson, B. (2008). The public venture capital challenge: The Australian case. Venture Capital, 10(1), 1-20.

Luukkonen, T., Deschryvere, M., \& Bertoni, F. (2013). The value added by government venture capital funds compared with independent venture capital funds. Technovation, 33(4-5), 154-162. https://doi. org/10.1016/j.technovation.2012.11.007.

MacMillan, I. C., Siegel, R., \& Narasimha, P. S. (1985). Criteria used by venture capitalists to evaluate new venture proposals. Journal of Business Venturing, 1(1), 119-128. https://doi. org/10.1016/0883-9026(85)90011-4.

Malmström, M., Johansson, J., \& Wincent, J. (2017). Gender stereotypes and venture support decisions: how governmental venture capitalists socially construct entrepreneurs' potential. Entrepreneurship Theory and Practice, 41(5), 833-860. https://oi.org/10.1111/etap.12275.

March, J. G., \& Olsen, J. P. (1989). Rediscovering institutions: the organizational basics of politics. New York: Free Press.

Martí, J., \& Quas, A. (2018). A beacon in the night: government certification of SMEs towards banks. Small Business Economics, 50(2), 397-413. https://doi.org/10.1007 /s11187-016-9828-4.

Mezias, S. J., \& Scarselletta, M. (1994). Resolving financial reporting problems: An institutional analysis of the process. Administrative Science Quarterly, 654-678. https://doi. org/10.2307/2393775.

Mouritsen, J. (1994). Rationality, institutions and decision making: reflections on March and Olsen's rediscovering institutions. Accounting, Organizations and Society, 19(2), 193211. https://doi.org/10.1016/0361-3682(94)90018-3.

Ocasio, W. (1997). Towards an attention-based view of the firm. Strategic Management Journal, 18(S1), 187-206. https://doi. org/10.1002/(SICI)1097-0266(199707)18:1+3.0.CO;2-K.

Pache, A. C., \& Santos, F. (2010). When worlds collide: the internal dynamics of organizational responses to conflicting institutional demands. Academy of Management Review, 35(3), 455-476. https://doi.org/10.5465/amr.35.3.zok455.

Petersen, M. A., \& Rajan, R. G. (1995). The effect of credit market competition on lending relationships. The Quarterly Journal of Economics, 110(2), 407-443.

Petty, J. S., \& Gruber, M. (2011). "In pursuit of the real deal": a longitudinal study of VC decision making. Journal of Business Venturing, 26(2), 172-188. https://doi.org/10.1016 /j.jbusvent.2009.07.002.

Peng, M. W., Sun, S. L., Pinkham, B., \& Chen, H. (2009). The institution-based view as a third leg for a strategy tripod. Academy of Management Perspectives, 23(3), 63-81. https://doi.org/10.5465/amp.2009.43479264.

Pratt, M. G., Rockmann, K. W., \& Kaufmann, J. B. (2006). Constructing professional identity: the role of work and identity learning cycles in the customization of identity among medical residents. Academy of Management Journal, 49(2), 235-262. https://doi. org/10.5465/amj.2006.20786060.
Ruef, M., \& Scott, W. R. (1998). A multidimensional model of organizational legitimacy: Hospital survival in changing institutional environments. Administrative Science Quarterly, 877-904.

Scott, A. J. (2000). The cultural economy of cities: Essays on the geography of image-producing industries. Sage.

Scott, W. R. (2014). Institutions and organizations. Thousand Oaks, CA: Sage Publications.

Scott, W. R., \& Davis, G. F. (2007). Organizations and organizing, rational, natural and open system perspectives. New Jersey: Pearson Prentice Hall.

Sharma, A. K. (2015). Venture capitalists' investment decision criteria for new ventures: a review. ProcediaSocial and Behavioral Sciences, 189, 465-470. https://doi.org/10.1016/j.sbspro.2015.03.195.

Shultz, T. R., \& Lepper, M. R. (1996). Cognitive dissonance reduction as constraint satisfaction. Psychological Review, 103(2), 219. https://doi.org/10.1037/0033-295X.103.2.219.

Silva, J. (2004). Venture capitalists' decision-making in small equity markets: a case study using participant observation. Venture Capital, 6(2-3), 125-145. https://doi.org/10.1080 $/ 13691060410001675974$.

Simon, H. A., \& Barnard, C. I. (1947). Administrative behavior: a study of decision-making processes in administrative organization. Macmillan.

Souitaris, V., Zerbinati, S., \& Liu, G. (2012). Which iron cage? Endo-and exoisomorphism in corporate venture capital programs. Academy of Management Journal, 55(2), 477-505. https://doi.org/10.5465/amj.2009.0709.

Strauss, A., \& Corbin, J. (1990). Basics of qualitative research: grounded theory procedures and techniques. Newbury Park, CA: Sage Publications, Inc..

Thornton, P. H. (2004). Markets from culture: Institutional logics and organizational decisions in higher education publishing. Stanford University Press.

Thornton, P. H., Ocasio, W., \& Lounsbury, M. (2012). The institutional logics perspective: a new approach to culture, structure, and process. Oxford University Press on Demand.

Tavory, I., \& Timmermans, S. (2014). Abductive analysis: theorizing qualitative research. University of Chicago Press.

Tolbert, P. S., David, R. J., \& Sine, W. D. (2011). Studying choice and change: the intersection of institutional theory and entrepreneurship research. Organization Science, 22(5), 13321344. https://doi.org/10.1287/orsc. 1100.0601.

Trevino, L. J., Thomas, D. E., \& Cullen, J. (2008). The three pillars of institutional theory and FDI in Latin America: an institutionalization process. International Business Review, 17(1), 118-133. https://doi.org/10.1016/j.ibusrev.2007.10.002.

Wright, M., Thompson, S., \& Robbie, K. (1992). Venture capital and management-led, leveraged buy-outs: a European perspective. Journal of Business Venturing, 7(1), 47-71. https://doi.org/10.1016/0883-9026(92)90034-O.

Yin, R. K. (1994). Case study research design and methods: Applied social research and methods series (Second ed.). Thousand Oaks, CA: Sage Publications Inc.

Zacharakis, A. L., \& Shepherd, D. A. (2001). The nature of information and overconfidence on venture capitalists' decision making. Journal of Business Venturing, 16(4), 311-332. https://doi.org/10.1016/S0883-9026(99)00052-X. 
Zajac, E. J., \& Westphal, J. D. (2004). The social construction of market value: institutionalization and learning perspectives on stock market reactions. American Sociological Review, 69(3), 433-457. https://doi.org/10.1177 /000312240406900306.

Zhang, Y. (2018). Gain or pain? New evidence on mixed syndication between governmental and private venture capital firms in China. Small Business Economics, 51(4), 995-1031.
Zucker, L. G. (1977). The role of institutionalization in cultural persistence. American Sociological Review, 726-743. https://doi.org/10.2307/2094862.

Publisher's note Springer Nature remains neutral with regard to jurisdictional claims in published maps and institutional affiliations. 